Author: Kolehmainen Marjo.The material politics of stereotyping white trash: flexible classmaking. The Sociological Review.2017,65,2,pp. 251-266. Copyright (C 2017 The Author(s). Reprinted by permission of SAGE Publications. DOI:10.1177/0038026116681440.

\title{
The Material Politics of Stereotyping White Trash: Flexible Class-Making
}

\section{Introduction}

This article examines emerging discussions of 'white trash' in a Finnish online forum. The term white trash has apparently become sufficiently globalised to circulate at least online in Finland, but how is it understood and used in such a new context for class-making? Naming class also makes class (Tyler 2013, 174); hence these online discussions signal novel ways of class-making. Employing conventional class names has been criticised for essentialism and for limiting our understanding of transformations in class relations (Tyler 2015, 507). This is evident in regard to online discussions of white trash, which represent a rupture that cannot be fully conceptualised through conventional class categories, as the term is not widely used in Finland. However, the examination of online discussions allows access to debates concerning issues generally seen as sensitive, as boundary-making around social class can be a delicate topic (Katainen and Seppälä 2008, 42). Furthermore, examining the debates produces new knowledge about ambivalent forms of class-making in Finland, including how class is made through racialisation. Theoretically, I draw on previous literature on the interconnectedness of race and class, especially on international work on the stigmatisation of the white poor - whether the latter is named white trash, the white working class or something else. In my study, the term white trash is not straightforwardly linked with the underclass, working class or middle class, as I will later argue in more detail. As a result of my examination, I introduce four alternative ways the term is used: as part of the transnational stigmatisation of the white poor; as a novel and expansive way to make distinctions; as an ambivalent way to stereotype even exclusive consumer choices; and as a synonym for ordinariness.

I have not come across any conversations about white trash in Finland other than in the online forum. There the raising of white trash as a topic is seen as provocative, meaning that such threads gain popularity as participants open, read and comment on them. Analysing the forum in question reveals a sort of folk sociology of class: the online debate demonstrates some popular ideas about class and the use of lay class concepts and conceptualisations (see Sayer 2005, 70-71). The threads also provide a very specific way of framing class and race against a specific contextual background. When white trash is discussed, it is not in relation to either class or race as explicit categories: the discussions concern, for example, education, poverty and especially taste. Hence I will use the concepts of taste and distinction to introduce the processes of class-making (see Bourdieu 1986). My aim is not to reduce class to taste, but rather to use these concepts as tools to access some of the symbolic dimensions of struggles over and against classificatory systems - here mainly the 
interconnectedness of class and race. Finns' tastes have already been studied extensively, from music and literature to sports and food cultures (Purhonen et al. 2014). Recent studies have also touched upon taste in the context of nightclubs and music scenes (Katainen and Seppälä 2008), omnivorous musical tastes (Alasuutari 2009), and the ways in which the idea of 'good' taste is used to reinforce gender conformity (Kolehmainen 2012a). However, the ways in which people explicitly perceive and discuss class and taste have barely been examined. To my knowledge, this study is the first attempt to trace the processes of classification and stigmatisation around white trash in contemporary Finland. Despite the empirical focus on Finland, this article's basic ideas and arguments also contribute to research on class-making beyond Finland.

\section{Background: white trash in Finland?}

'White trash' has a history as a stigmatising phrase. The term does not refer to the often-invisible normative whites, but to the hyper-visible 'filthy whites' (see Tyler 2008, 25). The term has its origins in 15th-, 16th- and 17th-century England in bourgeois conceptions of the white poor as immoral, lazy and criminal (Wray 2006, 135). In the US from the early 1700s onwards, whites who did not respect the dominant moral boundaries regarding property, work, gender arrangements and colour lines preceded the birth of the category of white trash (Wray 2006, 17). Nowadays white trash is associated with the image of backward, ignorant, racist and poor Southerner whites living in trailer parks (eg Hartigan 1997; Wray 2006). In the UK, the word 'chav', alongside its synonyms and variations, has become a ubiquitous term of abuse for white working-class subjects (Tyler 2008, 17). In Australia, similar attributes are associated with 'bogans', although 'white trash' has more rural connotations than 'bogan' (bogans are supposedly suburban) or 'chav' (supposedly urban) (Loughnan et al. 2014, 54). However, despite their differences, all the variations can be understood as part of 'class-making', in which the white upper and middle classes attempt to distinguish themselves from poor whites (see Tyler 2008, 18; Skeggs 2005). Seeing the white poor as racist, useless, pointless and an obstacle to global modernity is a functional figuring that allows the middle class to position themselves as the vanguards of cosmopolitan modernity and to draw divisions between different forms of whiteness, thereby disrupting the order of white privilege (Skeggs 2005, 972; Skeggs 2004). The term 'white trash' has a counterpart (valkoinen roskasakki) in Finnish, but this is not commonly used.

There is no previous research on stereotypes concerning white trash in Finland, nor is the term often used in Finnish society. This does not straightforwardly signal an attempt to avoid this pejorative term, but rather is part of a general silence about race and class. Race and class are often seen as 
sensitive issues that are in tension with the egalitarian ideals of Nordic welfare societies. Finland is one of these Nordic welfare states, which are seen as exceptionally democratic (Alasuutari 2009, 81). However, the Nordic countries participated in colonial endeavours in multiple ways, (re)produced colonial imaginaries, and elaborated knowledge that placed 'whites' at the top of a racial hierarchy (Keskinen 2013). Nonetheless, even in most academic contexts, race as a concept is greatly avoided (eg Vuolajärvi 2014, 264-265), and hence whiteness has remained under-theorised (Puuronen 2011). 'Race' as a word has been associated with racist discourse and assumptions about the naturalness of race, whereas 'ethnicity' has been viewed as a more neutral term prioritising culture over nature (Vuolajärvi 2014, 275, 282-283; Puuronen 2011, 29). Race has been almost a forbidden word, and as a consequence many speak not of racism but of discrimination - a term that makes no explicit reference to race (Puuronen 2011, 51). Only recently has whiteness started to receive academic attention (eg Keskinen 2013; Vuolajärvi 2014).

Class too has been described as a sensitive issue in Finland (Erola 2010, 20; Melin 2010). The civil war in 1918 was first and foremost a class war in which the bourgeoisie and the working classes fought against each other. By the Second World War the Finns had more or less united as a nation, but in civil society there remained a division between the winning camp and the losing camp for decades in the aftermath. This division was evident in newspapers, sports, theatre and banking as well in chain stores. Not until the 1980s did the polarisation of civil society come to an end (Nieminen 2014, 42-43). As a consequence of the civil war and the national trauma that followed, class has been a loaded topic, and talking about class has often been seen as inappropriate (Melin 2010,212 ). In the 1970s, class as an issue was straightforwardly associated with politics, especially leftist and even communist politics (Melin 2010). In the 1980s it was announced that class-based polarisation had been overcome, and Finns were seen as a mass of middle classes (Melin 2010). Research studies on class have been greeted with reluctance in the social sciences, and internationally recognised academic trends declaring the death of class have also been identifiable in Finland (see Melin 2010, 212-215). It has become common to claim that Finland is not a 'classbased society' (Erola 2010, 19).

Terms such as 'white trash' highlight the ways in which racism and classism intersect. Satnam Virdee (2014) pays attention to the ways in which class relations are both made and unmade through the prism of race. Writing about the historical making of the working class in England, he demonstrates how racialised groups have included Irish Catholics, for example; hence racism is not a straightforwardly colour-coded phenomenon. Similarly, racialised groups are often classed. Stuart Hall pinpoints how black labourers have been seen as a class in the UK (Hall 1980, 340-341). In a 
similar vein, the term 'underclass' - which later came to designate the white poor in the UK (Murray 1996) - has its origins in the stigmatisation of urban African Americans. The term emerged in US journalism in the late 1970s and early 1980s. Although American social scientists had used the term before, at the end of the 1980s 'underclass' was being used to refer to urban blacks. The term was imported into the UK soon afterwards. Scholars and journalists propagating the term were later criticised for popularising it, and in some cases also for pathologising inner-city black life. (Lister 2004, 107-108.) It has been pointed out that in addition to race and class, gender also plays a significant role in the interconnected processes of racialisation and classification. For example, Kimberlé Crenshaw (1989) examines how both feminist and anti-racist discourse has failed to take into account the experiences of women of colour positioned simultaneously as both female and black, arguing that the intersection of racism and sexism cannot be fully captured by looking at race or gender separately.

In Finland too, race and class intersect in many ways. Finnish identity has been produced by distancing Finns from significant others, namely the Russian population and the Sámi people (Puuronen 2011). The traditional minority groups consist of Swedish-speaking Finns, a significant language minority; Sámi people, whose indigenous status is recognised by the EU; and Roma people. In particular Russians, Somalis, Muslims and migrants in general have been subjected to a racialisation that categorises people on the basis of their language, religion or traditions and then maps and naturalises the groups produced as homogeneous (Puuronen 2011, 57). As in several other European countries, in Finland many minorities or migrant groups are white (see Garner 2006, 268). Other established minority groups include Russians, Jews and Tatars, who have been assimilated to a great extent but have often retained their religion (Puuronen 2011, 57). Of these traditional groups, the Swedish-speaking population is particularly subject to class-based stereotypes which portray them as wealthier and in all ways 'better' than ordinary Finns (Heikkilä 2011, 22). By contrast, several non-white migrant groups are often categorised as underclass in Finnish public debate. Katariina Mäkinen (2016), who has studied anti-migration online activism, pinpoints how Roma people and Somalis are believed to be economically redundant and are thus seen as a 'burdensome' underclass or surplus population.

\section{Research data and methodology}

My methodological approach draws on online ethnography as well as textual analysis. I examined a particular discussion forum where 'white trash' was regularly discussed (see Hine 2000 on virtual ethnography). I conducted online observations on the discussion forum in question over a period of 
two years in the 2010s, including a year of mostly daily observations (by computer and/or smartphone). I did not take part in the discussions. Soon I noticed the predominance of the Englishderived abbreviation 'WT' when participants were referring to 'white trash'. Therefore I used 'WT' as a search term when, at the end of my non-participant observation, I extracted for rigorous study all of the threads on white trash that had been opened during the six months from 1 October 2013 to 31 March 2014. I archived all the threads on white trash that matched the chosen time span and had WT or similar terms in their topic titles. My search yielded 52 threads. For the purposes of this study, the five most popular threads were chosen as objects for detailed analysis, comprising 817 messages altogether. In these threads, a quiz designed to test one's own white-trash features generated 238 messages; a thread on attraction to white-trash men generated 181; a total of 171 messages discussed white-trash homes; the career and education of a self-declared 'WT' mother generated 115 messages; and a thread on the specific characteristics of white-trash aeroplane passengers generated 112 messages. Three of the five threads focused on identifying white trash suggesting the (re)invention of a powerful classificatory system.

My analysis was tentatively guided by my non-participant observations. The simple recognition that the stereotype of white trash is indeed being discussed in Finland was a point of departure for this study. This recognition became a data 'hot spot' that 'glowed' (MacLure 2013) as it pushed me to explore the phenomenon further. While analysing the threads I traced the ways in which white trash was being defined. My analysis was informed by my familiarity with previous studies on classbased stigmatisation, and I wanted to examine whether the class-making processes around the stereotype of white trash were similar to or different from those found in accounts originating in other countries.

I gave every thread a letter code. T referred to the thread on measuring one's own WT features; A to the thread discussing attraction to 'WT men'; H to the thread on homes; E to the thread on education and careers; and $\mathrm{P}$ to the thread on passengers. I also gave every comment a numeric code, eg E1 designated the first comment on the thread debating education and careers. I also organised my data thematically. However, my data analysis method can best be described as thinking with theory (see St Pierre \& Jackson 2014), and the codes served only as a means of identifying quotations. In what follows I will use the codes when introducing quotations from the data. While it is sometimes worth paraphrasing direct quotations from informants in order to make them difficult to find using search engines (see Boellstorff et al. 2012, 140), I decided to leave my quotations untouched, as all of my data is easily accessible, widely available and public. However, the quotations have been translated from Finnish into English. 
The forum explored is among the most popular online discussion forums in Finland. It has approximately 400,000 visitors each week (SanomaMagazines: Mediaopas) - a considerable number, since Finland has only 5,450,000 inhabitants. Although use of the Internet nowadays is mobile and flexible, the language - almost without exception Finnish - limits participation to Finnish-speaking Finns (ie those for whom Finnish is their first or second language) living in Finland or abroad, or to migrants who have at least basic language skills. The forum is part of a wider online portal, the website of a magazine aimed at parents of infants. There are several forums for debate, discussion and peer support. These forums usually require user registration, and there are distinct subsections, eg for pregnancy and childbirth, or infertility and adoption. In addition to general debate, it is possible to discuss sex, tourism and different family-oriented blogs without user registration. However, my focus is on the general conversation section, which is organised around peer conversation. Here the participants can post comments without registration and thus they remain anonymous. Discussion is moderated retrospectively, and messages breaking the law or forum rules are deleted.

The general debate section is massive in volume, with hundreds of discussions ongoing daily. Topics cover almost anything, including social class. Reading, opening threads, responding, discussing, debating and giving a thumbs-up or thumbs-down are among the interactive activities available to a basic user. Statistics and my own observations suggest that occasional lurking is probably the most common way to use the forum in question. It is noteworthy that several participants seem to form some sort of online community, although it is important to acknowledge that not every user is a regular and to avoid making generalisations or assuming a coherent community (see Boellstorff et al. 2012, 57). Many invest in the forum by participating in conversations, opening new threads, offering peer support and so on. Some may just browse topics occasionally, and it is questionable whether the discussion forum serves as a community for them. It is also important to recall that regulars may experience the forum in different ways depending on how they contribute, which threads they open, when they go online and so on.

According to my observations, a significant number of regulars share an understanding of the online community as consisting mainly of mothers, and many are self-declared mothers; yet fathers and childless people also participate. Nevertheless, the community-originating caricature of a regular is a 'mummy', which is telling of the gendered understanding of this kind of activity. The participants seem to come from various backgrounds, including socio-economic backgrounds. The discussion is almost exclusively adults-only; teenagers are not welcome. Of course, it is beyond the scope of this study to find out who the participants 'really' are. However, it is problematic to consider online 
performances of self as less authentic than offline performances. A strict distinction between the two would be based on uneasy assumptions about both self and authenticity, as it would prioritise notions of singular, coherent selves (Hine 2000). Nonetheless, the question of authenticity seems important to the participants, as new topics are regarded with scepticism if they are judged to be unrealistic or deliberately provocative. Attempts to differentiate authentic openings from trolls take place, but members may also treat topics as if they are 'real' even when they doubt it - which highlights the simple pleasure of discussing.

In the forum there are occasionally threads that parody eg previous threads, so the tone of discussion is often humorous. It also seems that several participants see the white-trash discussions as humorous chitchat. It is indeed common for representations of social class to be mediated through caricatures (Tyler 2008, 19). The anonymity of the Internet increases the use of derogatory terms for potential opponents and aggravates interactions, and interviews would not give access to such picturesque, loaded classifications (see Katainen and Seppälä 2008, 42-43). Despite the often humorous tone, some participants seem to feel hurt, excluded and judged after reading about different markers of white trash, but attempts to criticise the classifications are often deemed as lacking a sense of humour. This highlights the ways in which humour is used to include and exclude: deeming a group as having no sense of humour is in fact a way of othering. Recognition and misrecognition are central to the processes of class-making (eg Sayer 2005; Skeggs 2005; 1997). A previous study of white working-class women in the UK found that they did not want to be recognised as working class and made efforts to avoid being seeing as such (Skeggs 1997, 74). However, in my data some respondents self-identify as 'WT'. This may be for several reasons: for example, the tone of discussions is experienced as entertaining, and thus self-identifying is not laden with shame; anonymity makes it possible to identify without concrete social sanctions; the term is not very common in Finland; and some may self-identify in order to resist systems of classification or their accuracy. In any case, it is worth asking for whom the term can function as a means of self-identification, and to whom the threads appear exclusive, hierarchical or stigmatising.

\section{Transnational stereotypes of white trash}

I always wanted to become an academic [...] I do not identify with the WT subculture involving binge drinking, smoking, watching the box, cohabiting and separating as well as leeching off social benefits with no conscience. (not to mention the stereotypical outfit with tattoos/heavy make-up/nail extensions/piercings) [E1] 
Broken dishes and cheapo kids' toys as well as empty beer cans and fizzy-drink bottles everywhere. Full bin bags lying in corners waiting for someone to take the rubbish out. Dirty clothes strewn about, with dust and fluff under the beds and in corners. [H26]

In several places the discussions seem almost identical with the stereotypes of the white poor identified in previous studies in other countries, especially the UK or US. As that earlier body of research demonstrates, the white poor are often seen as vulgar, excessive, fat, drunk, tasteless, ungovernable and atavistic (see Skeggs 2005, 965-966). My data also yielded these stereotypes. For example, the first extract [E1] conforms to the idea of excess as a signature feature of the white poor: binge drinking, nail extensions and piercings are listed as examples of white-trash characteristics. This message opened a thread on careers and education, and the writer provocatively claimed she had become WT against her will. The example illustrates how the term is used to categorise others but is also a means of self-identification. The message bears many of the hallmarks of trolling, however: it starts by setting up an opposition between WT and academic cultures; the 'wt mummy' who opened the thread responds to comments in a provocative way; and a significant proportion of her comments are written as if her only purpose is to keep the debate alive and heated. Nevertheless, only a few responses openly accuse the original writer of trolling, and a significant number of the responses offer support (eg advising her to get a degree in higher education). Hence the thread illustrates the effective way in which this online forum provides peer support.

Excess is also attributed to material objects in the data. The second example [H26] is a response to a thread on homes, where the original message invited respondents to list things found in 'WT homes'. The extract associates bad hygiene with the white trash stereotype, mentioning features from full bin bags to broken dishes. Several of these features also connote moral issues, such as empty beer cans, which refer to excessive drinking and the idea of mess. These classifications resonate with the moralising, pathologising, disgust-producing register attached to the working class in countries other than Finland (see Skeggs 2005, 967; Skeggs 2004). This highlights how people experience class in relation to others partly through moral sentiments, emotions and embodied judgements (Sayer 2005, 3). Attempts to question the correctness of the proposed categorisation indicate that people are likely to read the discussion as involving moral judgements - otherwise they probably would not invest in trying to exclude themselves from the description. Of course, attempts to criticise the term can be seen as involving moral judgements, too. 
One way to interpret the emergence of discussion of white trash in Finland is to elaborate on the connection between the new class vocabulary and the ways in which judgements might be indicative of middle-class security about taste. A crisis in middle-class authority and security has been called the zeitgeist of the moment (Skeggs 2005, 968). This holds true in Finland, where the position of the middle classes has become unstable. The general rise in educational levels has increased competition within the Finnish middle class. Higher education, for example, does not guarantee a high income or even a steady job. The size of the middle class conceals traditional differences between classes, and makes it difficult to identify specific middle-class characteristics (Kahma 2010, 93). However, previous studies have noted that middle-class respondents feel great security in their own judgement, and feel they have the power to judge (Kuipers 2006, 373). Hence it makes sense to assume that the crisis in middle-class authority and security might also manifest itself in the emergence, intensification and import of class-based conceptions.

\section{Endless distinctions}

Yellow bog roll. Can be found at our place. [H23]

[...] newest insta pic celebrates Ed Hardy theme day AGAIN. Couldn't she just admit that she likes the king of all wt brands [A158]

The attempts in my data to identify white-trash characteristics go way beyond the stigmatisations that have been noted internationally. Distinctions are made on the basis of what aeroplane passengers wear, which airline companies are preferred, or whether a tablet or a book is used to read a novel. Distinctions are made about almost anything, so much so that it is difficult to tell whether some are extreme distinctions or merely parodies of exclusive tastes. For example, my third example [H23] proposes that the colour of toilet paper marks the boundary between classes. It is a response to the thread where the original message requested a list of things to be found in 'WT homes'. Most of the messages in this thread did indeed add new items to the list, which was revealing of how threads produced and reproduced class stigma and contributed to the intensification of class-making. Previous studies have found that tastes are differentiated on the basis of eg genres, foods or sports. In my data, it is not only genres and brands that work as distinctions, but also songs within a given genre or products from a certain brand, and even the colour of toilet paper. This may pose a methodological challenge for future studies: sometimes a distinction can be identified only by looking beyond the level of genres or brands as markers against which distinctions are made. 
Several scholars have questioned the existence and viability of rigid taste hierarchies. Tastes are allegedly organised into coexisting taste cultures rather than hierarchies, and it has been suggested that tastes are increasingly fragmented (Kuipers 2006, 361-363). Recently, theorists have suggested that high-status groups are becoming omnivores whose tastes include both the exclusive and (parts of) the lowbrow (Peterson and Kern 1996). However, the existence of omnivorous tastes does not mean that taste does not mark social status or provide a means to climb up the social ladder. Omnivorous tastes are also selective (Alasuutari 2009). The extension of distinctions might perhaps be connected to the proliferation of omnivorous tastes: if current tastes fail to distinguish, returning to taste hierarchies and applying distinctions to even more areas than before may seem an attractive option. For example, my fourth extract [A158] positions a certain brand as WT. It is a comment on a thread discussing Finnish bloggers who have dated or are dating 'WT men'. They are not identified in the first message, but the responses make it possible to identify which blogs are being referred to, even for a reader who is not familiar with the blogs in question. In fact the thread focuses on a Finnish blogger and her Australian boyfriend. Many of the responses draw on previous knowledge of the blog or report (insider) knowledge. The boyfriend is disapproved of, mocked and parodied in several comments, especially because pictures he has published on social media (eg of him passing out, and of a penis tattoo) are regarded as tasteless. However, tastelessness is extended to the blogger too - for example, her preference for Ed Hardy clothing is criticised.

The fact that distinctions are made about almost anything might signal a shift towards the fragmentation of taste, an increase in omnivorous tastes or the coexistence of different tastes. It might be interpreted as a concrete example of middle-class security about taste (Kuipers 2006). The act of making of distinctions has been interpreted as serving the bourgeois project of selfconstitution, which distinguishes the middle class from its others (Lawler 2005, 443). Attributing negative value to the working class is a mechanism for attributing value to the middle-class self (such as making oneself tasteful by judging others to be tasteless). It is a matter not just of using some aspects of working-class culture to enhance one's own value, but also of maintaining one's judging position in order to attribute value that labels the other as immoral, repellent, abject, worthless, disgusting or even disposable (Skeggs 2005, 977). In this way definitions of white trash are also objects of middle-class perception (Sullivan 2003, 54). This illustrates the status of consumer culture as an essential arena for class-making, which may itself privilege the position of the middle classes as makers of class. Both yellow toilet paper and Ed Hardy clothing are examples of the centrality of consumer choices in the processes of class-making online.

\section{Ambivalent economics}


Well I don't know any WT who have been to Thailand. The WT I know visit the Costa del Sol in Bulgaria, Tenerife and Turkey. And that doesn't even happen too often as those beach holidays cost money. [P101]

When WT become enthusiastic about 'decorating', it means that they start to bring home large flat-screen TVs and home-theatre gizmos, giant tasteless divan sofas and leatherette chairs. [...] [H119]

In the data, the relationship between money and white trash is highly ambiguous. In previous studies, white trash has been seen as a label for those who are not only poor but cannot help failing to hide it (Sullivan 2003; Tyler 2008; Wray 2006). The term explicitly positions the subjects associated with it as waste, and figures them as having no value (Hartigan 1997; also Skeggs 2011; Skeggs 1997). In my data too, lack of wealth and economic hardship are attached to white trash. Often these distinctions articulate moral judgements - stolen beer mugs, unemployment and repossession orders are mentioned - and thus speak to Andrew Sayer's argument $(2005,17)$ that moral evaluations of self and others relate to, but are not reducible, to class. However, moral judgements in my data also cover certain car brands, high-end lamps or trips to Thailand - all priced so high that they are unlikely to be affordable for all consumers.

Thus there are attempts to identify white trash on the basis of investments in interior design or expensive travel destinations, and this distances the class-making process from stigmas concerning poverty in particular. Distinctions are made on the basis of how people behave on aeroplanes or where they go for their holidays abroad. My fifth extract [P101], for example, is a comment on the thread discussing WT passengers. The provocative opening message asked how to identify WT aeroplane passengers. Many of the subsequent messages were comments on previous responses rather than the original question. The opening message mentioned certain cities in Thailand as travel destinations, which led to arguments over whether trips to Thailand could be seen as WT. Thus distinctions are not straightforwardly linked with finances in my data. Class concerns about consumerism are visible in my data, and it almost seems as if consumption is in crisis.

White trash has been seen as an inevitable part of modern industrial capitalism, which requires both a concentration of wealth and cheap, expendable labour (Sullivan 2003, 54). However, it seems that the relationship between white trash and capitalism cannot only be understood in terms of the tension between capital and labour. In addition to poverty, an inability to behave like a good consumer seems to recur in characterisations of white trash. My sixth example [H119] further demonstrates that the white-trash stereotype does not require assumptions concerning lack of 
wealth. By contrast, the 'wrong' kinds of consumer choice are classified as WT. In this example, large TVs and home-theatre sets, as well as certain kinds of furniture, are judged. Imogen Tyler (2008, 21-22) has remarked on a similar shift in the emergence of the figure of the chav. She acknowledges that this figure differs from previous accounts of the underclass in its emphasis on the excessive consumption of branded goods. Indeed, the chav is primarily identified by its 'bad', 'vulgar' and excessive consumer choices. Hence, in the context of shifting class definitions, the vilification of the chav can be interpreted as a symptom of a middle-class desire to re-demarcate class boundaries within the context of contemporary consumer culture. Hence it makes sense to infer that boundary work manifests itself in a nuanced struggle over consumer choices.

\section{Struggles over ordinariness}

I got 33 points, get over it!!!! I'm a 28-year-old single parent with four kids by three different dads and I've been married twice. I've dropped out of business college and vocational college as well as evening classes, and had two abortions, I have five tattoos etc. [...] In my opinion, I think you should get extra points for owning several Moomin mugs, or having Unikko curtains in the kitchen [...][T57]

[...] Our home is an Ikea-free zone. We only drink Japanese or Chinese organic green tea. $[\ldots]$ We don't consume Hermesetas or other artificial sweeteners. We own the original Artichoke lamp by Poulsen. [...] [H18]

The things characterised as white trash in my data can often be described as ordinary. This is surprising, as ordinariness has been associated with middle-classness in previous studies. For example, the English respondents in Savage et al. (2001, 887-888) who identified as working class or middle class expressed a strong desire to be read as 'ordinary'. In Finland, ordinary has even been seen as a euphemism for middle class (Soronen 2007). It seems that many commentators seek to distinguish themselves from the mass of middle classness, and in order to succeed, they classify any popular thing as WT. Several things that are ordinary, popular or trendy rather than abject are classified as white trash, and it seems that once a designer item becomes well known and widely used, it loses its power to act as a distinction. For example, my eighth example [T57] mentions Moomin mugs (by Finnish designer label Iittala) and Unikko curtains (by another Finnish designer label, Marimekko). The comment is a response to a quiz including a long list of different characteristics classified as potential markers of white trash, varying from being unemployed to having bright red or jet black hair. However, to be able to state that certain brands such as Iittala or Marimekko are 'WT', as proposed in the comment, one first must have the cultural resources to 
recognise them as valued cultural objects that conventionally symbolise good taste. Even though the backgrounds of the online participants are not known, it seems likely that discussions of white trash are also used to conduct boundary work within the middle classes rather to distinguish the middle class from the working class. When, as Beverley Skeggs (2005) writes, culture can be propertised in the making of the middle-class self, it seems that cultural capital is converted into symbolic capital by producing a distance from the 'ordinary' middle class; and in my data, capitalisation upon distinctions acts as a means of attaching value to proper subjectivities.

The tastes of the (actual or perceived) masses are thus classified as 'WT' in my data. In this example [T57], Moomin mugs and Marimekko curtains - Unikko refers to an iconic fabric that was once the most popular of all Marimekko prints - illustrate how the tastes of the masses are not valued. This is telling of the value attached to individualism. Individualism has historically been a middle-class project, and the working classes have been positioned as the masses against which individualism is constructed (Skeggs 1997, 164). In addition, white trash is defined by positioning some consumers as immobile. The failure to follow the latest trends is categorised as white trash, as the mugs and curtains represent past rather than future trends. Previously, anti-fashion vocabulary has been seen as a feature of non-working-classness in the UK (Skeggs 1997, 85). In the data, WT are thus positioned as those who follow trends but do not set them. The inability to embody modernity has been a key attribute attached to the working classes (Skeggs 1997; Skeggs 2005). It seems that in my data, both a failure to be a trendsetter and an excessive fondness for fashion are labelled as white trash, in contrast with independent, individual consumers.

Similarly, the eighth example [H18] mentions things that can be seen as imitating good taste or the latest trends. It is a response to the thread on WT homes, where the opening comment listed items including plastic flooring and Marilyn Monroe pictures. What is characteristic of both these items is that they refer to things seen as faux: instead of having a wooden floor or parquet, one has plastic flooring; instead of hanging paintings on the wall, one has pictures of a famous film star. Similarly, the example above disapproves of an Ikea lamp that resembles an original designer lamp by Poulsen, and mentions artificial sweeteners. Although authenticity is sometimes associated with the working class, it seems that when it comes to material objects, the dividing line between the authentic and the faux is a strong indicator of boundary work in class-making. Such comments seem to chime with the Bourdieusian argument concerning the taste hierarchy. Bourdieu (1986) states that the upper classes are seen to have good taste. As they also have high levels of social status, the subordinate classes eventually cannot help mimicking them. His view has since been criticised for assuming that taste simply trickles down. Furthermore, what is essential for the continued existence 
and popularity of these elite versions of taste is a structured hierarchy and cycle. Selected sensibilities that originate at the top of the hierarchy gradually slide downwards to the lower extremities. However, once their downward journey commences, the cycle starts again, with the upper strata once more needing to adopt and create new fashions and distinctions so that their power to determine taste will continue (Galilee 2002, 38). In a similar vein, items mimicking things once considered hip are judged as WT in my data.

\section{Conclusion}

In this article, I have introduced four alternative ways the term white trash is used in a Finnish online forum: as part of the transnational stigmatisation of the white poor; as a novel and expansive way to make distinctions; as an ambivalent way to stereotype even exclusive consumer choices; and as a synonym for ordinariness. It is remarkable that there is no consensus in the data on the meaning of the term 'WT', or on whether the term should be used at all. The online forum in question is an easily accessible and well-known social space whose participants do not seem to represent any specific social group, although many of them are (or are assumed to be) mothers. Some participants resist the term white trash or the attempts to classify, whereas others seem eager to list 'WT' characteristics. Even though several of the comments are intended to resist and correct the definitions, these comments rarely question the existence of white trash or the symbolic value of taste. Nevertheless, the term white trash can signal almost anything, from having yellow toilet paper to travelling to Thailand, and from binge drinking to buying a designer lamp. Hence the term has become detached from its origins and is understood in ambivalent ways in Finland. However, ambivalence itself is essential for many forms of social reproduction in late-modern societies (Skeggs 2004, 29; Kolehmainen 2012b, 992). Although often praised for its ambiguity, ambivalence has become a means to reroute existing power relations. Indeed, the online conversation demonstrates that categories are often produced in a flexible, relational manner (also Cerwonka 2008, 824).

Discussions about white trash do not only maintain, resist and produce stereotypes of white trash. They also include several explicit or implicit indicators of middle- and upper-classness, and especially of the (assumed) tastes of those classes. The examination of taste may offer a novel route if we wish to study how privilege works in order to undo social hierarchies. Writing about popular culture and taste, Giselinde Kuipers $(2006,363)$ notes that scholars have focused on the ways in which popular culture can be 'read', rather than on the many ways people keep their tastes 'unreadable' to others. My study indicates that keeping tastes unreadable is an essential form of 
reproducing class - and if the tastes become widely recognised, new taste cultures are adapted to and new future fashions looked for. However, comparison with a study of anti-migrant online debates in Finland reveals something relevant to the essence of taste. A number of migrant groups, such as Somalis, are often defined as underclass on the basis of their assumed inability to work, earn and save (Mäkinen 2016), but not of their assumed lack of taste. In my data, white trash are defined by their assumed lack of taste, not by their inability to work or gain wealth. It thus seems that taste is an essential means of making class within a certain ethnic group. Why taste, then? One potential interpretation is that migrant groups are excluded from the discourses of taste: 'their' taste is assumed to differ from 'ours', or they are viewed as lacking culture of any kind.

It is also remarkable that much of the conversation about white trash focuses on consumption. This illustrates the status of consumer culture as an essential arena for class-making. What to buy and where to shop, for example, appear significant in struggles against and over classificatory systems. Hence it is worth asking whose interests this focus on consumption serves. I argue that rooting the online debate in consumer culture privileges middle-class interests and prioritises certain forms of class-making, which is itself already embedded in hierarchical social relations. Against this background it is not so surprising that questions of whiteness in particular or race in general are rarely openly addressed. All of the threads, as well as the features mentioned within them, might also be read as discussions of 'white culture', but this does not happen. It seems that the online discussions function as ways to 'teach' how to recognise white trash and produce a knowable figure of a 'WT' person in Finland (cf Tyler 2013, 166). Interestingly, the existence of classes in Finland is occasionally openly resisted, but this is not the case with whiteness or race. When discussing class explicitly, the threads often centre on white trash, even if there are occasionally topics on upper-middle-class habits etc. These topics lack any attempts to racialise the middle or upper classes; nor is whiteness debated elsewhere. Whiteness itself remains invisible until social class makes it visible, which is telling of the normative status of whiteness, and of the related silence. 
References:

Alasuutari, P., (2009), ‘Snobismista kaikkiruokaisuuteen: musiikkimaku ja koulutustaso’, in:

Liikkanen, M., (ed), Suomalainen vapaa-aika: Arjen ilot ja valinnat, 81-100, Helsinki: Gaudeamus.

Boellstorff, T. et al., (2012), Ethnography and Virtual Worlds: A handbook of method, Princeton: Princeton University Press.

Bourdieu, P., (1986), Distinction: A Social Critique of the Judgment of Taste, London: Routledge.

Cerwonka, A., (2008), 'Traveling Feminist Thought: Difference and Transculturation in Central and Eastern European Feminism', Signs: Journal of Women in Culture and Society 33(4): 809-832.

Crenshaw, K., (1989), 'Demarginalizing the intersection of race and sex: A black feminist critique of antidiscrimination doctrine, feminist theory and antiracist politics', University of Chicago Legal Forum 14: 538-554.

Erola, J., (2010), 'Johdanto', in his (ed), Luokaton Suomi? Yhteiskuntaluokat 2000-luvun Suomessa, 19-26, Helsinki: Gaudeamus.

Galilee, J., (2002), ‘Class consumption. Understanding Middle-Class Young Men and Their Fashion Choices', Men \& Masculinities 5(1): 32-52.

Garner, S., (2006), 'The Uses of Whiteness: what sociologists working on Europe can draw from US research on whiteness', Sociology 40(2): 257-275.

Katainen, A. and P. Seppälä, (2008), 'K-junalla Sedulaan. Luokkataustaiset makuluokittelut Helsingin yöelämässä’, Kulttuurintutkimus 25(4): 37-52.

Hall, S., (1980), 'Race, Articulation and Socities Structured in Dominance', in UNESCO (ed.) Sociological Theories: race and colonialism, Paris: UNESCO.

Hartigan, J. Jun. (1997), 'Unpopular culture: The case of 'white trash', Cultural Studies 11(2): $316-343$.

Heikkilä, R. (2011), Bättre Folk, Bättre Smak? Suomenruotsalaisten maku ja kulttuuripääoma, Helsinki: Helsingin yliopisto, sosiaalitieteiden laitoksen julkaisuja 2011:5.

Hine, C., (2000), Virtual ethnography, London: Sage. 
Kahma, N., (2010), 'Keskiluokan valossa: suomalaisten luokkasamastuminen empiirisessä tarkastelussa', Sosiologia 47(3): 81-96.

Katainen, A. and P. Seppälä, (2008), 'K-junalla Sedulaan. Luokkataustaiset makuluokittelut Helsingin yöelämässä’, Kulttuurintutkimus 25(4): 37-52.

Keskinen, S., (2013), 'Antifeminism and White Identity Politics: Political antagonisms in radical right-wing populist and anti-immigration rhetoric in Finland', The Nordic Journal of Migration Research 3(4): 225-232.

Kolehmainen, M., (2012a), 'Managed makeovers? Gendered and sexualized subjectivities in postfeminist media culture', Subjectivity 5(2): 180-199.

Kolehmainen, M., (2012b), 'Tracing ambivalent norms of sexuality: Agony columns, audience responses and parody', Sexualities 15(8): 978-994.

Kuipers, G., (2006), 'Television and taste hierarchy: the case of Dutch television comedy', Media, Culture \& Society 28(3): 359-378.

Lawler, S., (2005), 'Disgusted subjects: the making of middle-class identities', The Sociological Review 53(3): 429-446.

Lister, R., (2004), Poverty, Cambridge: Polity Press.

Loughnan, S., \& N. Haslam \& R. M. Sutton \& B. Spencer (2014), 'Dehumanization and Social Class: Animality in the Stereotypes of "White Trash", "Chavs", and "Bogans" '. Social Psychology 45(1): 54-61.

MacLure, M., (2013) Classification or wonder? Coding as an analytic practice in qualitative research, in Coleman, B., \& J. Ringrose (eds.), Deleuze and research methodologies, 164-183, Edinburgh: Edinburg University Press.

Melin, H., (2010), ‘Tarvitaanko vielä luokkatutkimusta?', in Erola, J., (ed), Luokaton Suomi? Yhteiskuntaluokat 2000-luvun Suomessa, 211-226, Helsinki: Gaudeamus.

Murray, C., (1996), Charles Murray and the Underclass: The Developing Debate,. The IEA Health and Welfare Unit Choice in Welfare No. 33. 
Mäkinen, K. (2016), 'Maahanmuuttovastainen liikehdintä, uusliberaali ideaalikansalaisuus ja ylijäämäihmiset', in Anttila, A-H. \& R. Kauranen \& K. Launis \& J. Ojajärvi (eds.), (2016), Luokan ä̈̈ni ja hiljaisuus. Yhteiskunnallinen luokkajärjestys 2000-luvun alun Suomessa, 247-276, Tampere: Vastapaino.

Nieminen, H., (2014), Tiedollisten yhteismaiden lyhyt historia. Tiemerkkinä Suomi, in Lehtonen, M., \& K., Valaskivi \& H., Kuusela (eds.), (2014), Tehtävä kulttuurille. Talouden ja kulttuurin munttuvat suhteet, 39-6, Tampere: Vastapaino.

Purhonen, S., et al., (2014), Suomalainen maku. Kulttuuripääoma, kulutus ja elämäntyylien sosiaalinen eriytyminen, Helsinki: Gaudeamus.

Puuronen, V., (2011), Rasistinen Suomi, Helsinki: Gaudeamus.

Savage, M. et al., (2001), 'Ordinary, Ambivalent and Defensive: Class identities in the Northwest of England', Sociology 35(4): 875-892.

Sayer, A. (2005), The Moral Significance of Class, Cambridge: Cambridge University Press.

Skeggs, B., (2011), 'Imagining personhood differently: person value and autonomist working-class value practices', Sociological Review 59(3): 496-513.

Skeggs, B., (2005), 'The making of class and gender through visualizing moral subject formation', Sociology 39(5): 965-982.

Skeggs, B., (2004), 'Context and Background: Pierre Bourdieu's Analysis of Class, Gender \& Sexuality', in Skeggs, B. and L. Adkins (eds), Feminism After Bourdieu, 19-35, Oxford: Blackwell.

Skeggs, B., (1997), Formations of Class and Gender: Becoming Respectable, London: Sage.

Soronen, A., (2007), 'Sisustusohjelmien kodit parannellun tavallisuuden näyttämöinä', Lähikuva 20(2): 8-26.

St. Pierre, E. A., \& A. Y. Jackson (2014), 'Qualitative Data Analysis After Coding', Qualitative Inquiry 20(6): 715-719.

Sullivan, N., (2003), 'Academic Constructions of White Trash', in Adair, V. C. and S. L. Dahberg (eds), Reclaiming class. Women, poverty, and the promise of higher education in America, 53-66, Philadelphia: Temple University Press. 
Tyler, I., (2015), 'Classificatory struggles: class, culture and inequality in neoliberal times', The Sociological Review 63(2): 494-511.

Tyler, I., (2013), Revolting Subjects: social abjection and resistance in neoliberal Britain, London: Zed Books.

Tyler, I., (2008), “'CHAV MUM CHAV SCUM”: Class disgust in contemporary Britain', Feminist Media Studies 8(1): 24-34.

Virdee, S., (2014), Racism, Class and the Racialized Outsider, Basignstoke: Palgrave Macmillan. Vuolajärvi, N., (2014), 'Rotu etnisten suhteiden tutkimuksessa', in Irni, S. and M. Meskus and V. Oikkonen (eds), Muokattu elämä, 264-301, Tampere: Vastapaino.

Wray, M., (2006), Not Quite White: White Trash and the Boundaries of Whiteness, Durham: Duke University Press. 